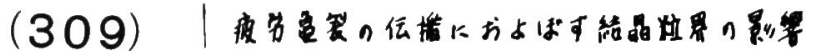

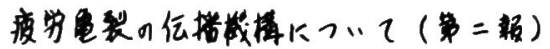

$$
\text { 千童工業大学 }
$$

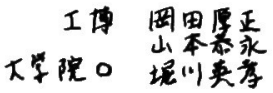

\title{
I. 绪言
}

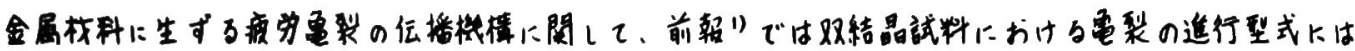

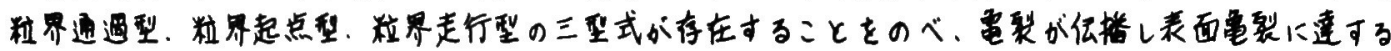

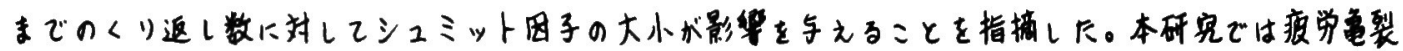

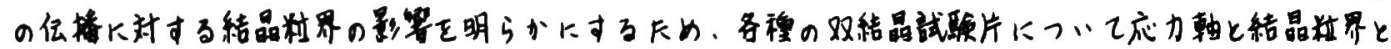

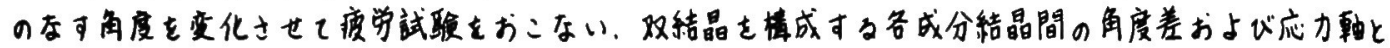

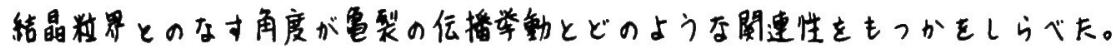

2. 实㩆方法

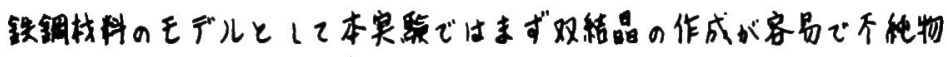
をどの影特の少ない99.99\%高能度アルミニうムを用い下。

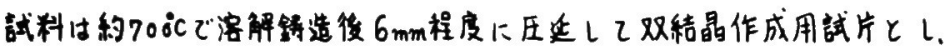

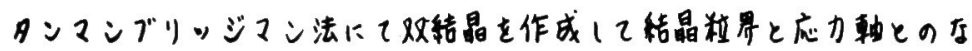

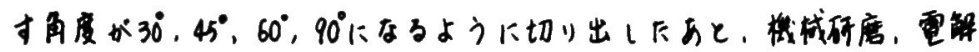

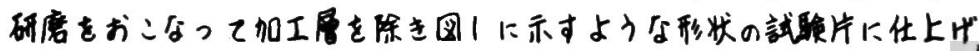

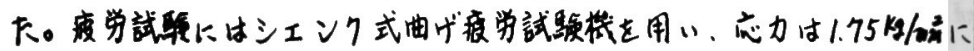

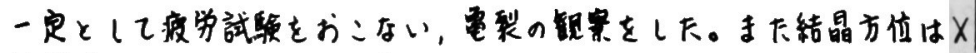
特背面ラウ工法を用いて测定した。

\section{3. 实跙結果}

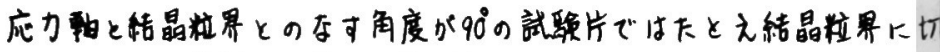

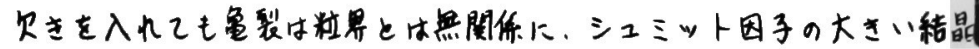

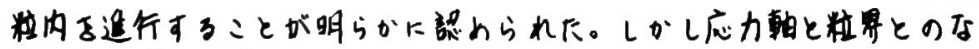

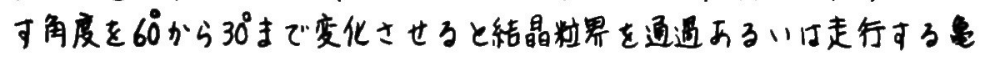

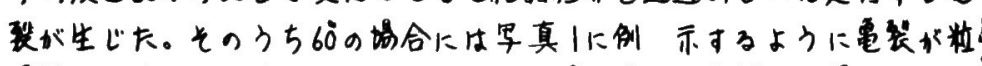

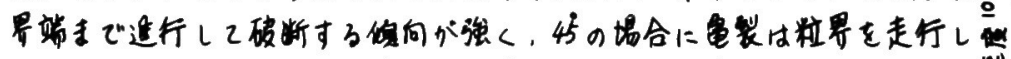

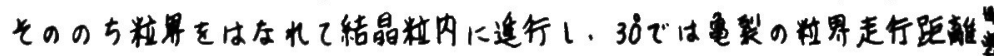
がさらに短かくなる颉向が認められた。すなわら粒界の方向がせん断方 向下近ブくにつれて象裂が粒界飞走行する倾向が增大しさらに再者のな

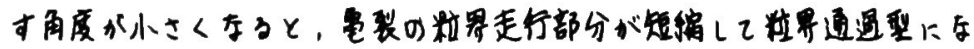

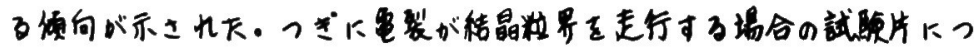

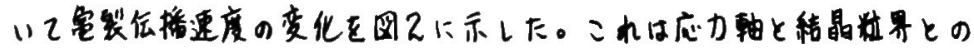

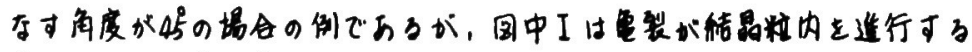

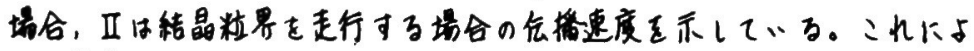

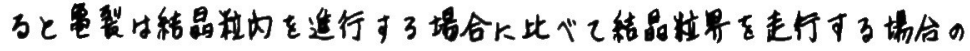

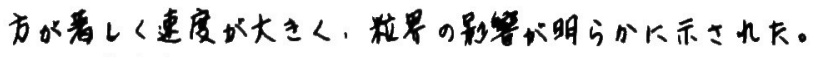

各考文旅

1)周田，开田铁上銅 V 0160 (1974) P 264

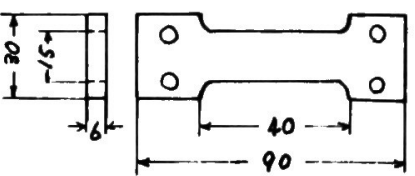

回 1、試騕片形状

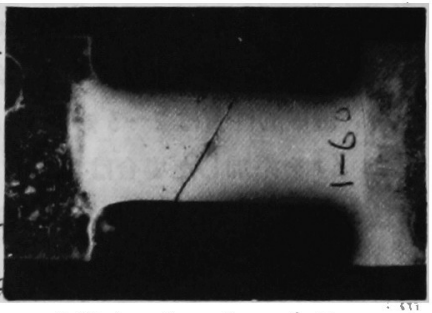

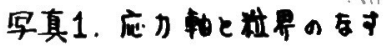

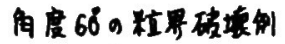

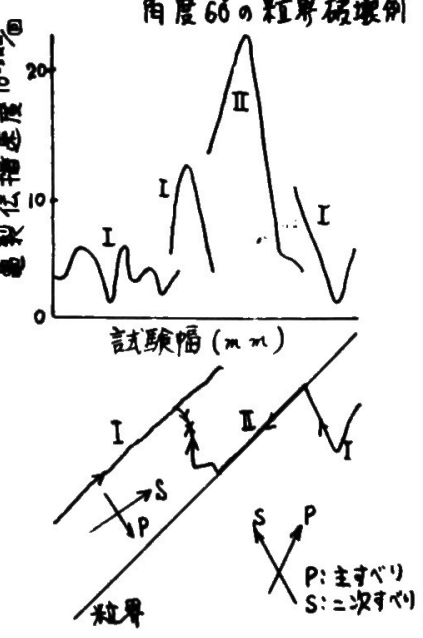

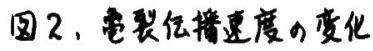




\section{（310） SNCM8鋼の程り返(応力ーひすみ状態。}

金属栰料技街研究所

\section{○田中荰一 \\ 松四三郎}

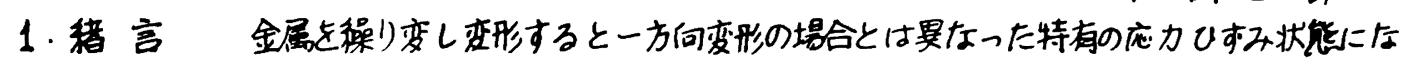
そことはよく知られており，龹の状態を表りすのに稆り返し応力いすみ曲使用すること加多い。こ

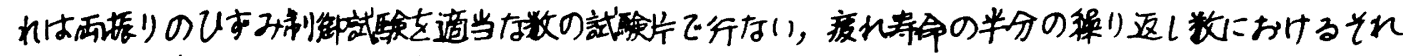

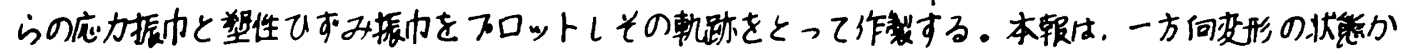

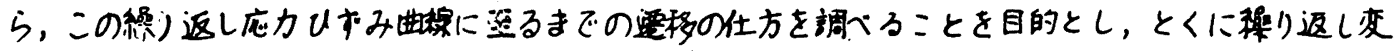

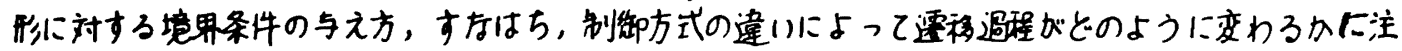

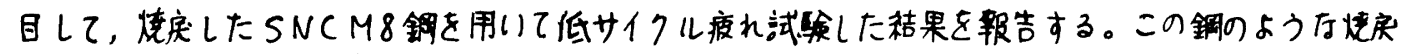

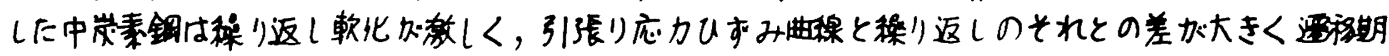
办野微下表的れる。

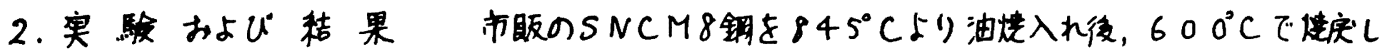

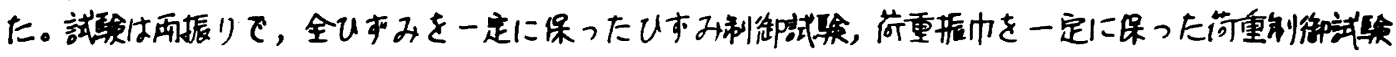

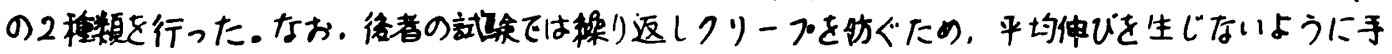

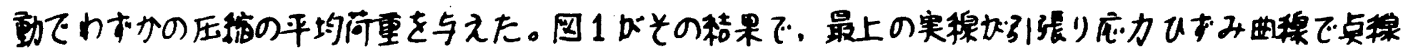

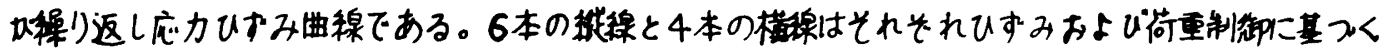

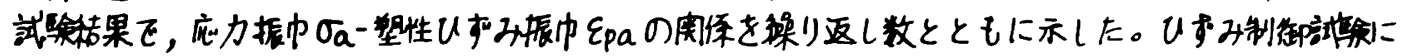

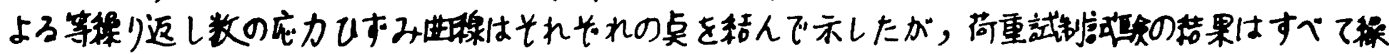

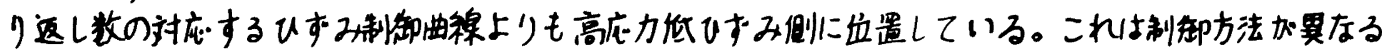

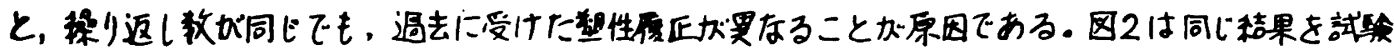

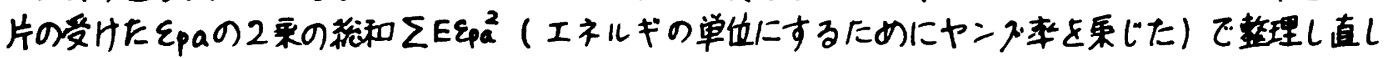

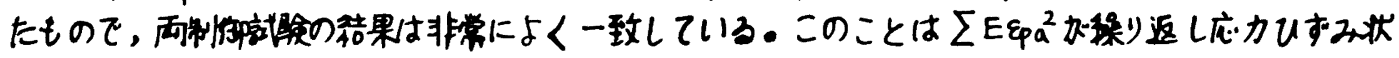
態を記述する状態变数であることを示す。

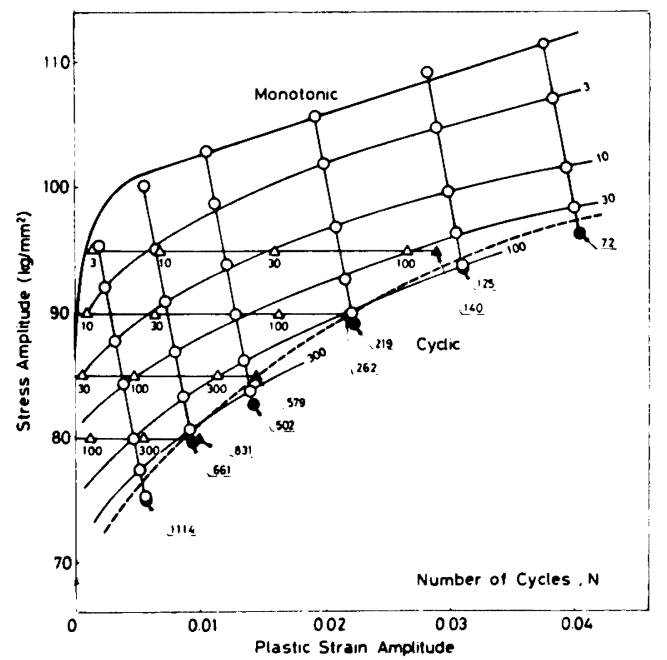

因1.程り返し庇力U机み曲楾( 变教; N)

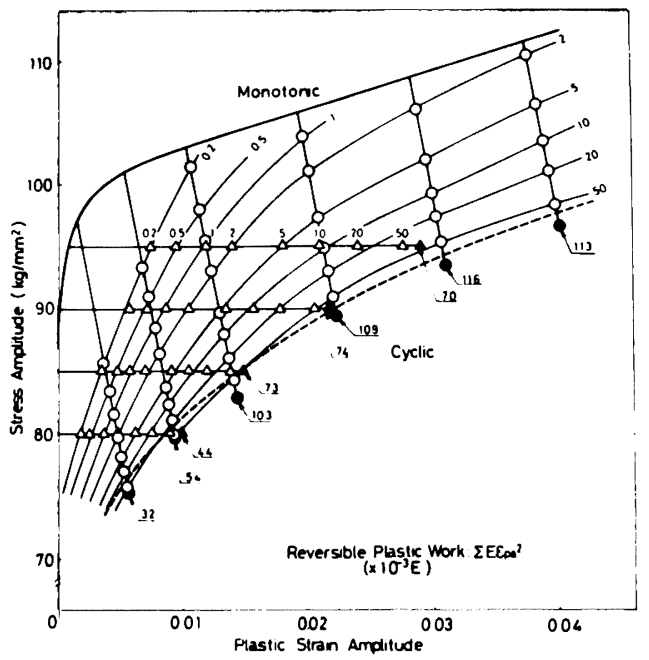

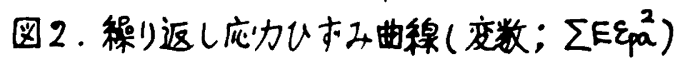




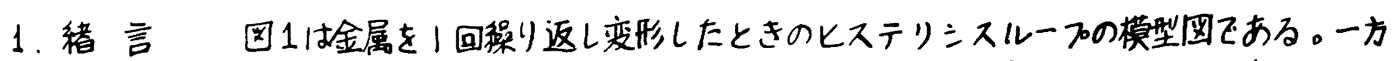
向の变形による応力ーUずみ曲腺OABにおいて，A卓て除荷し迸方向の变形を与えると，变形がすべ 乙不可逆に起るならはA桌で降伏し，ABをたどるはすである。しかし、实祭は逆方向の变形ては降伏 はA桌以下で起こり，关の後の变形応力もABより低い。これは福り返し变形においては，何らかの工

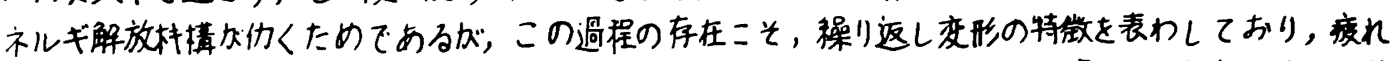
組较を定める重要な要因となっていると考えられる。とくに分散強北型合金の場合，分散相に基入く道

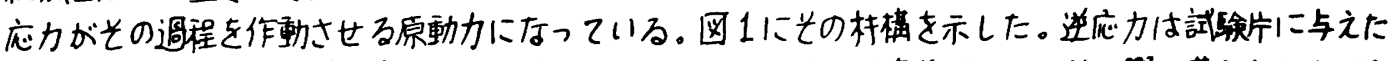

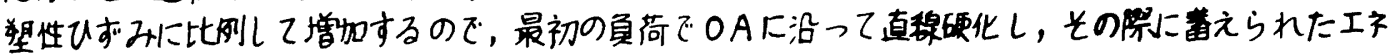

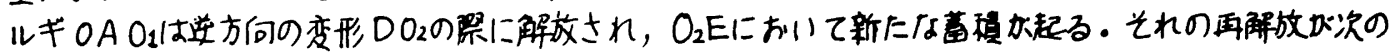

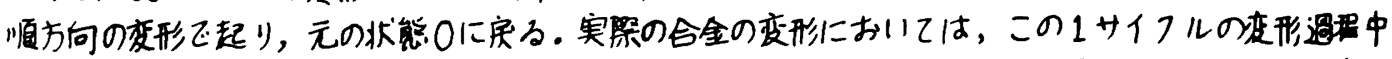

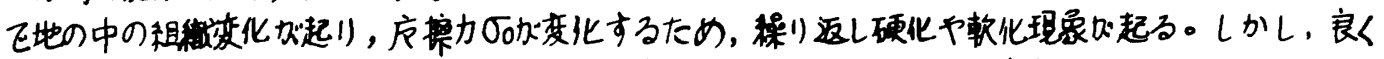
知られているように，艺れらの現象は新り返し变形の初期起るがすぐに安定化し，ルーフ・は同じ形状

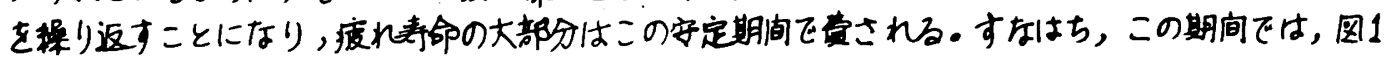
の模型が良く成り立つであろうと予想して上下の实鈋を行った。

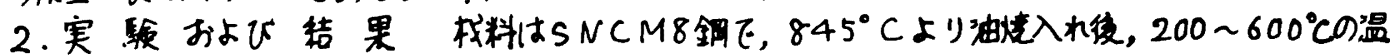

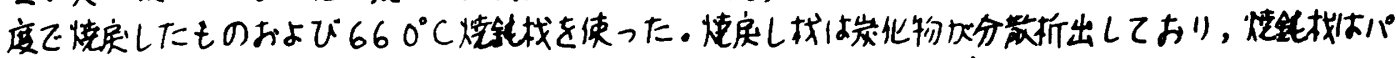

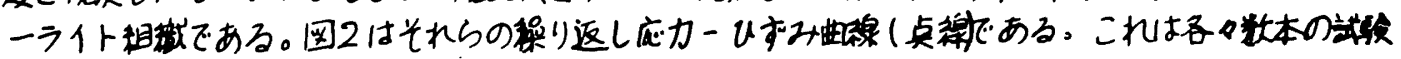

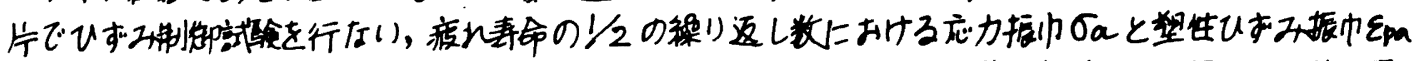

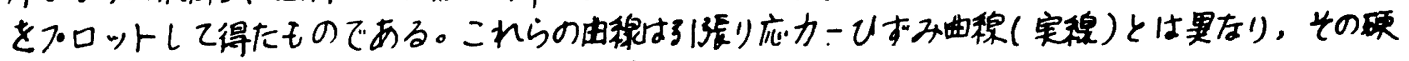

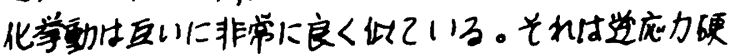
化を仮定して次式より計算した使化挙動(一卓銷稳) と良く一致している。(E：铁のヤ二市率(21000 kg/man) $\frac{d \sigma_{a}}{d \varepsilon_{p a}}=\frac{(7-5 \nu)}{10\left(1-\nu^{2}\right)} \frac{E f}{(1-f)}\left\{\begin{array}{l}\nu: \text { 铁のポアンン比 }(0.3) \\ f: \text { 定化物の含有量 }(0.062)\end{array}\right.$

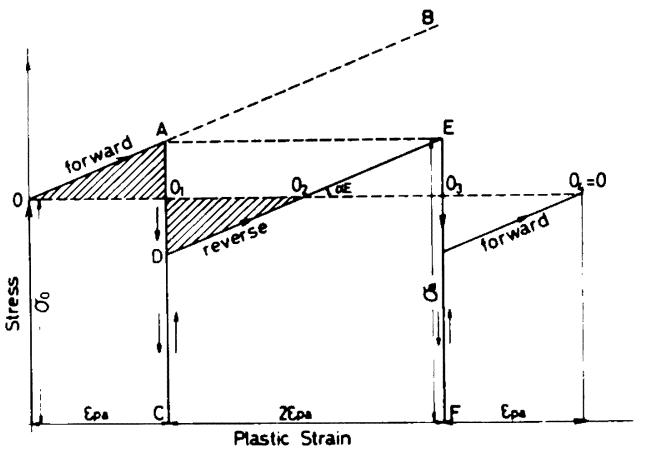

图1迸底力効果の模式説明

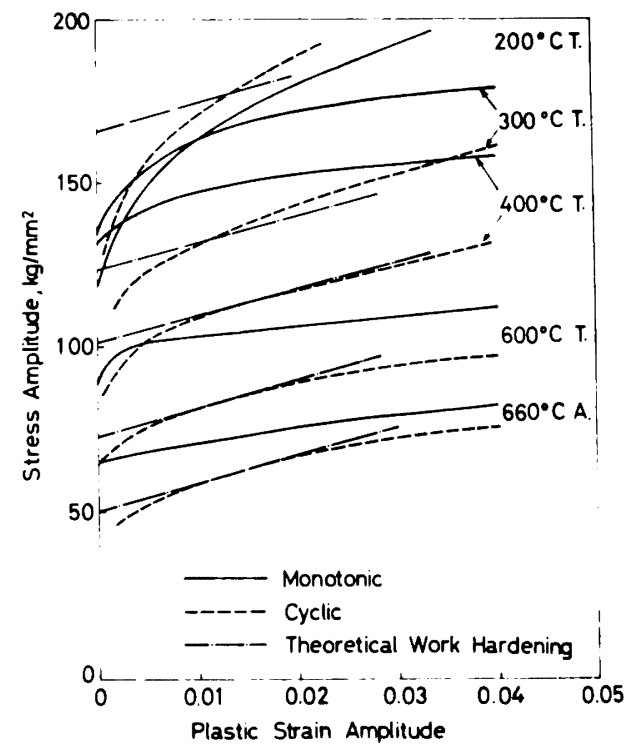

因2.SNCM8程り返し応力Uすみ曲楾 


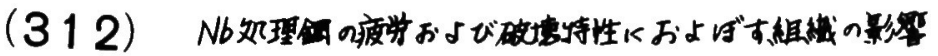

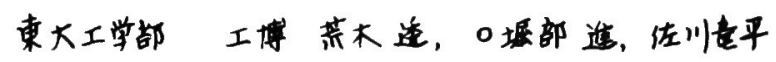

\section{1. 绪言}

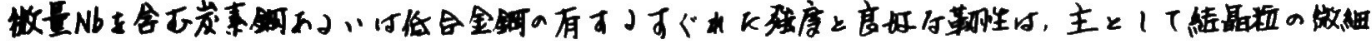

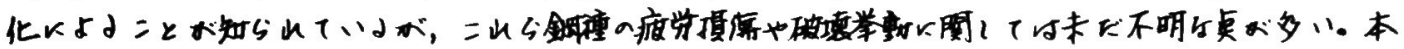

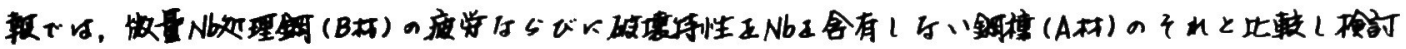

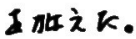

\section{2. 实锒方法}

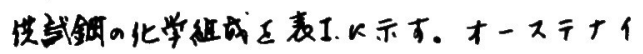

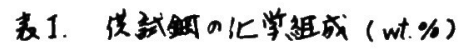

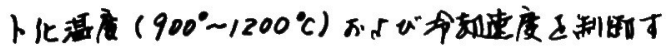

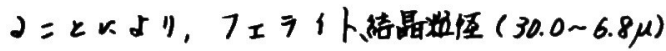

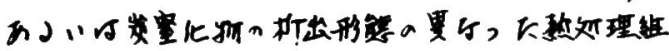

\begin{tabular}{|c|c|c|c|c|c|c|c|c|c|c|c|}
\hline & $C$ & Si & Mn & P & S & Ni & Cr & Cu & Nb & sol.Al & TN \\
A & 0.19 & 0.44 & 1.36 & 0.020 & 0.018 & 0.02 & 0.02 & 0.04 & - & 0.028 & 0.0040 \\
\hline & 0.20 & 0.17 & 1.25 & 0.020 & 0.020 & 0.01 & 0.02 & 0.03 & 0.029 & 0.031 & 0.004 \\
\hline
\end{tabular}

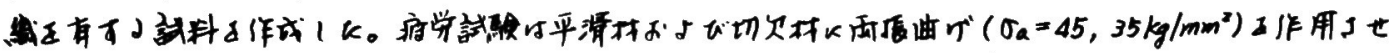

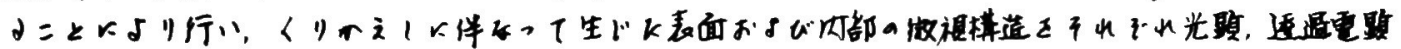

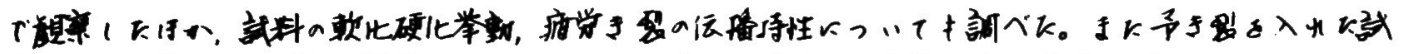

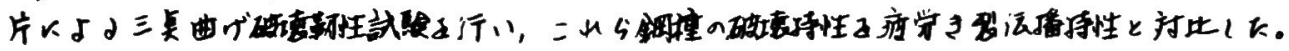

3. 实期结果

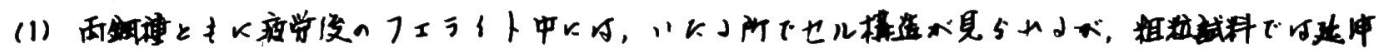

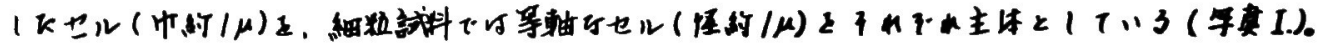

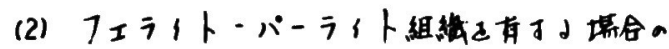

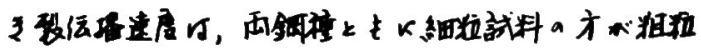

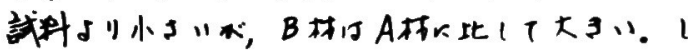

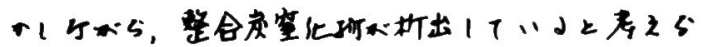

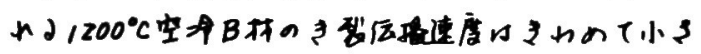

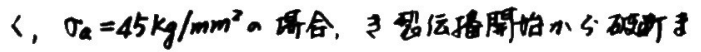

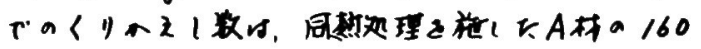
$\% k+$ 及只 (因I).

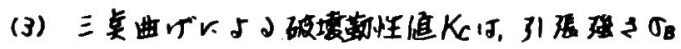

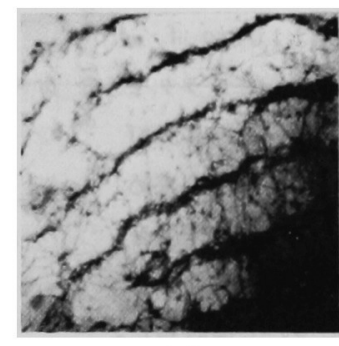

(a) $1100^{\circ} \mathrm{C} \mathrm{FC}$

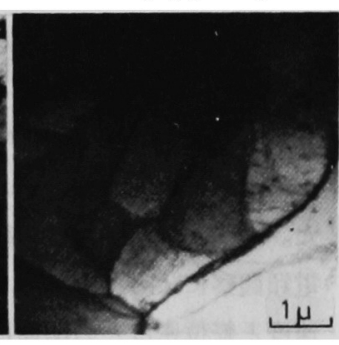

(b) $900^{\circ} \mathrm{CAC}$

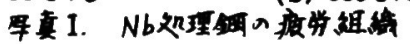

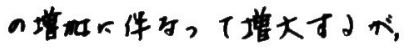

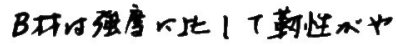
垬子(四2)。

(4) 上既部片破面的 $1200^{\circ} \mathrm{C}$

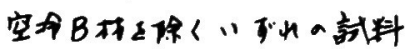
キデ、よTル主体上するボ,

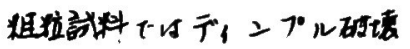

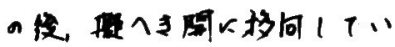

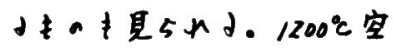

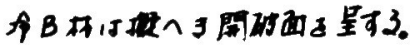

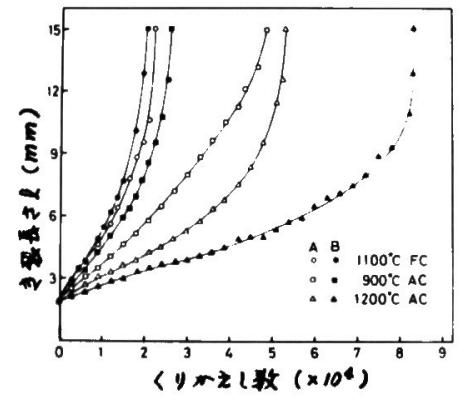

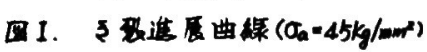

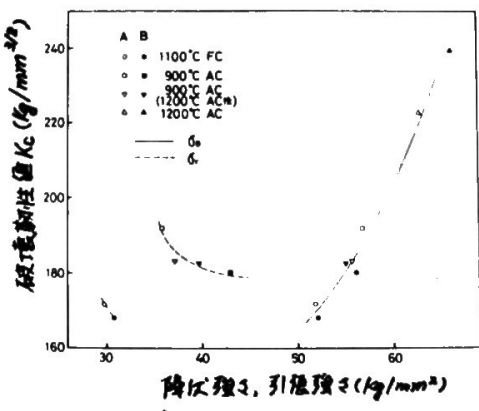

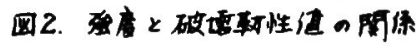


（313）中炭素鋼のレラクセーション速度におよぼす予付加塑性歪の影響

住友金属工業（侏）中央技術研究所工博大野铁 ○相原 賢治

I 目 的 表 1 供試材の成分と機械的性質

中炭素鋼の焼人焼戻組織および完全焼鈍 組織に各種歪量の塑性変形を加えた後レラ クセーション試験を行ない,レラクセーシ ヨンと結晶内部の転位の状況との関係につ いて調査・考察をした。

\section{I実験方法}

表 1 亿示す成分の中炭素鋼 3 種を $10 \varnothing$ 飞熱延後, 1及びロ材は $900^{\circ} \mathrm{C} \times 15$ 分 $\rightarrow$ 妒冷, 上材は $890^{\circ} \mathrm{C}$ 水焼人 $\rightarrow 350^{\circ} \mathrm{C}$ 焼 戻した。その後, 平行部 $8 m m \phi \times 150 m m \ell$ の試験片を製作し，インストロン試験機を 用いて室温にて歪速度約 $1 \times 10^{-8} / \mathrm{sec}$ で 及びロ材は $0.1 \sim 20 \%$.り材は $0.1 \sim 1.5 \%$ の 塑性伸びを付加した。 歪付加後直ちに植 桿式レラクセーション試験機でレラクセー ション試験を行なった。初期応力はイ及 びロ材は $30 \mathrm{~kg} \mathrm{f} / \mathrm{mm}^{\circ}$ D材は $100 \mathrm{~kg} \mathrm{f} / \mathrm{mm}^{\mathrm{m}}$. 試験温度 $20^{\circ} \mathrm{C} \pm 0.5^{\circ} \mathrm{C}$ である。レラクセ ーション曲線から $28.6 \mathrm{~kg} \mathrm{f} / \mathrm{mm}$ 及び $99 \mathrm{kgf}$ 啋におけるレラクセーション速度を求め た。また，各種歪付加後の全転位密度を 電影観察によって求め, レラクセーション 速度と転位密度との関係について検討した。

III結果及び考察

付加した塑性歪量とレラクセーション速

\begin{tabular}{|c|c|c|c|c|c|c|c|c|c|}
\hline & C & $\mathrm{Si}$ & Mn & $\begin{array}{r}\text { Sol } \\
\text { Al }\end{array}$ & $\begin{array}{c}\text { Total } \\
\text { N } \\
\end{array}$ & $\begin{array}{c}\mathrm{TS} \\
(\mathrm{kg} / \mathrm{mt})\end{array}$ & $\begin{array}{c}\mathbf{Y P} \\
(\mathrm{kg} / / \mathrm{d}) \\
\end{array}$ & $\begin{array}{c}E \\
1 \\
001\end{array}$ & $\begin{array}{r}R A \\
\text { Pol }\end{array}$ \\
\hline 1材 & 0.27 & 0.24 & 1.26 & $<001$ & 0.0140 & 53.9 & 35.4 & \begin{tabular}{|l|}
28.8 \\
\end{tabular} & \begin{tabular}{|l|}
31.6 \\
\end{tabular} \\
\hline 口材 & 0.28 & 0.24 & 1.29 & 0.028 & 0.0115 & 55.0 & 32.8 & \begin{tabular}{|l|}
24.3 \\
\end{tabular} & \begin{tabular}{|l|}
38.9 \\
\end{tabular} \\
\hline D材 & 0.39 & 0.28 & 0.76 & 0.033 & 0.0044 & 154.3 & 137.8 & 8.2 & 37.5 \\
\hline
\end{tabular}

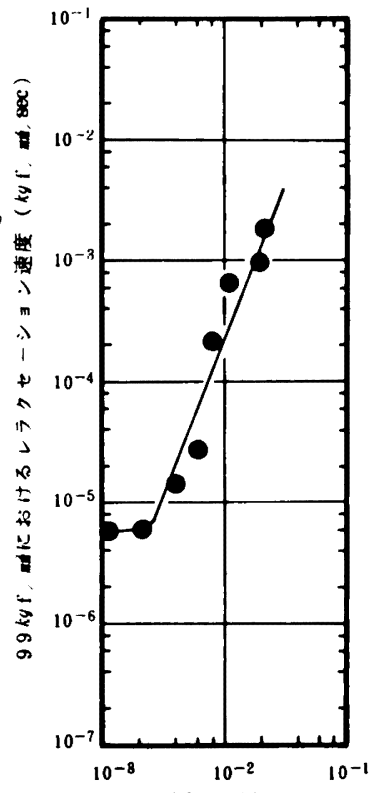

付加望性歪

図 1 焼入烛戻材での付加塑性 歪量と $99 \mathrm{kgf} / \mathrm{mm}$ 亿お けるレラクセーション速度 の関係

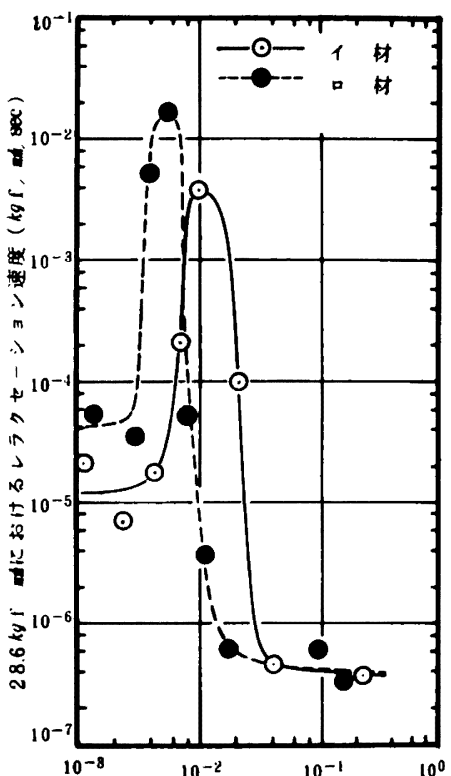

付加塑性歪

図 2 完全焼鈍材の付加塑性稆 量と $28.6 \mathrm{kgf} / \mathrm{m}^{2}$ におけ るレラクセーション速度 の関係

度との関係を 図1，図2に示す。焼人焼戻材てはリューダース変形以降の歪付加領域でレラクセーショ ン速度の対数と歪の対数とか直線関係にあり，勾配は約 2.5 になっている。一方完全焼鈍材ではりューダー ス変形直後にレラクセーション速度は付加歪量と共に急增し, 歪量 $1 \%$ 以上では逆に歪量の增大に伴なって減 少する。

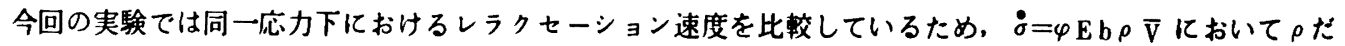

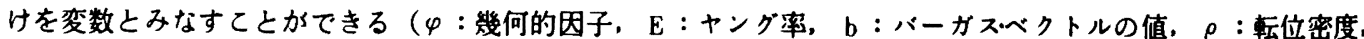
$\overline{\mathrm{V}}$ : 転位の運動速度）。焼人焼戻材では $\rho$ は $\varepsilon^{2.5}$ に比例し，完全烵鈍材では $1 \%$ 内外を極大とする急激な增 加一減少函数になっている。全転位密度は歪の增加と共に直線的に增加する（高歪領域では增加率は钝る）と とから、レラクセーション速度は可動転位密度に支配され，塑性歪を加えると焼人焼戻材では転位の增殖より あ固着転位の可動化か䫓著に進行し，完全焼鈍材では転位の增殖によって可動転位密度が一且增大し，歪の增 加と共にそれらの不動化が進行すると考えられる。 
$669.15^{\prime} 24^{\prime} 26-194 \cdot 56-426: 539.3 / .4: 539 \cdot 389.3$

（314）オーステナイト采ステンレス䠀線の忍力緩利特性について

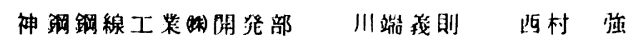

若宮辰也○山岡幸男

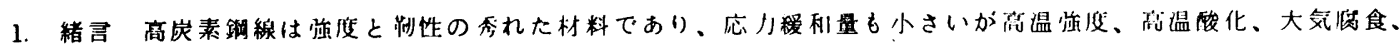

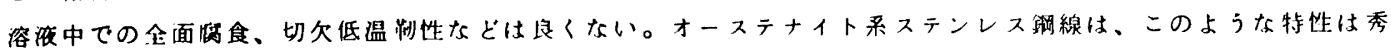

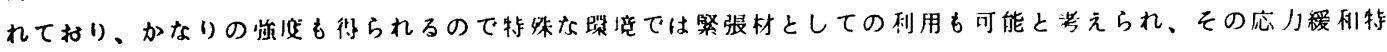

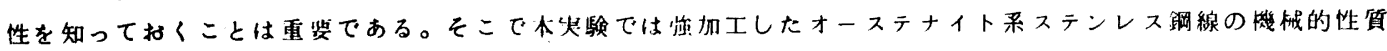

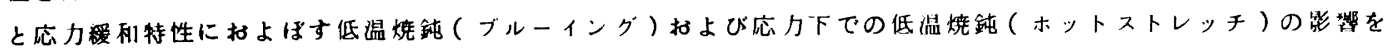
調べた。

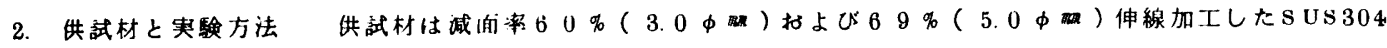
を用いた。ホットストレッチは図1に示す装羁を用い、線 が所定の温度に莘したのち5分閏加熱後空冷とした。スト

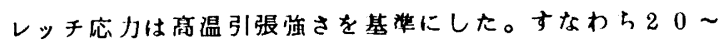
$525 \mathrm{C}$ 処理の場合はその温度の T. $\mathrm{S} \times 0.85$ とし.700 C 处理はその温度の T.S $\times 0.70$ とした。

5 分間の通宣加就のみを行なったものをブルーイング処理

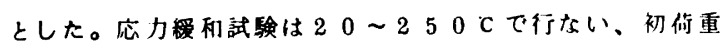
は試駼温度での引張強さの70\%とし、5または $10 \mathrm{hr} の$

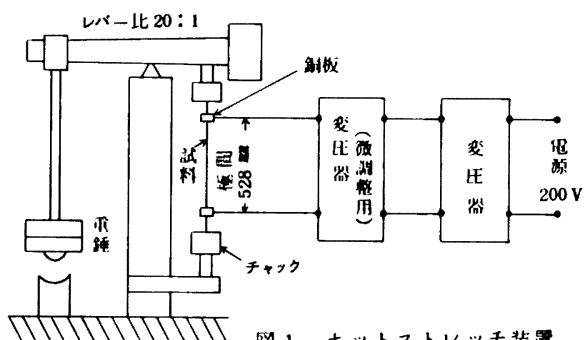
応力诚少量を求めた。

3. 実験結果四2〜四4に絬果を示す。要約すると次のようになる。

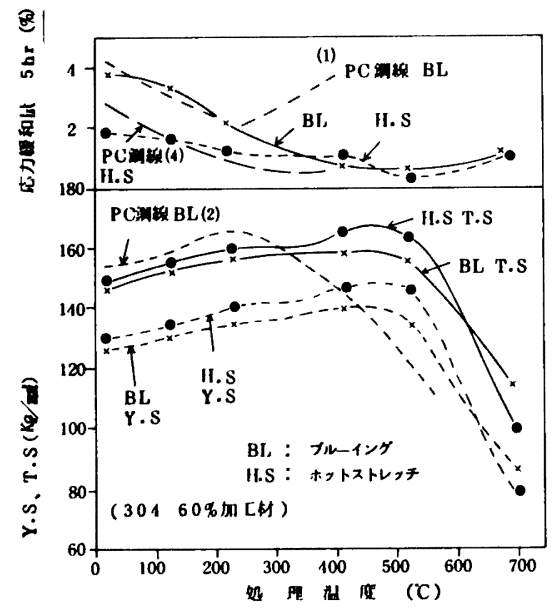

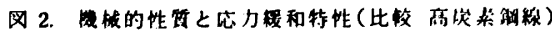

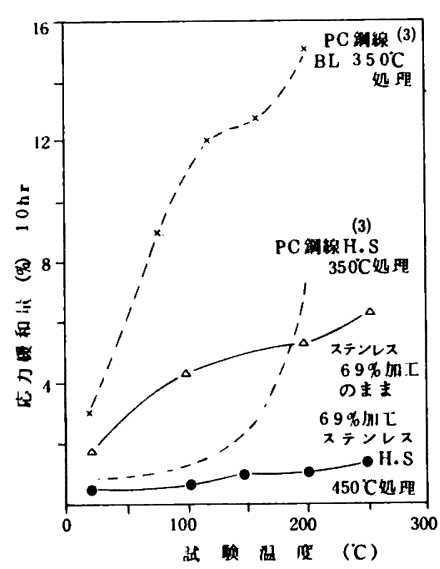

因3. 高温芯力和特性 （比筊高炭染铜線）

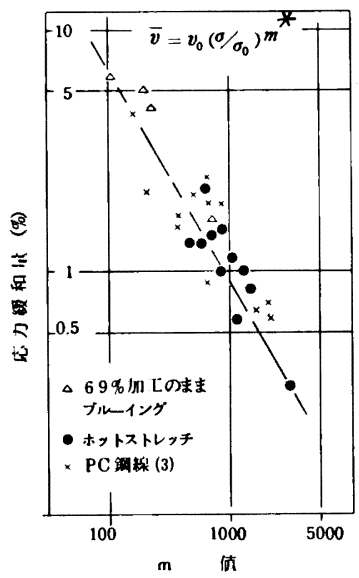

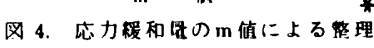

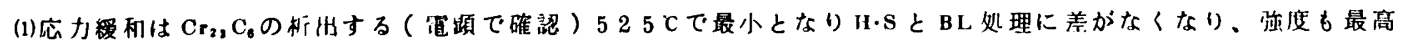

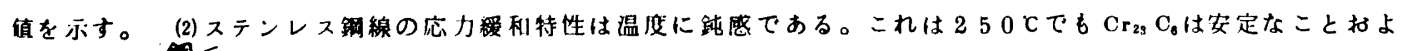
ひンテンレ在合金元秦を多く含み、すべり面も少ないことによると考えられる。 試駼条件にかかわりなく $\mathrm{m}$ 值で整理出来る。

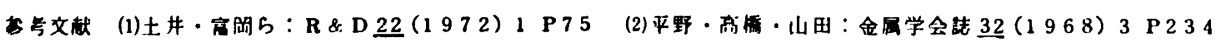

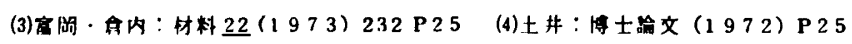


(315)高温ボルト用含Pオーステナイト系耐䓡銅につルて

1、緒 言

\begin{tabular}{|c|c|c|}
\hline 特殊製龬(株) & ○日下邦男 & 秋田光政 \\
\hline 本田技优研究所 & 大沢 恂 & 萩原好敏 \\
\hline
\end{tabular}

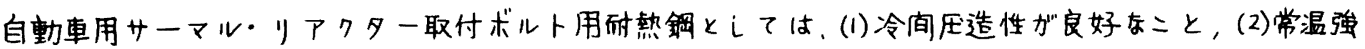
度が大きいこと，(3）600〜800足における高温強度が大きく，而酸化性の良好なことなどが要求さ水

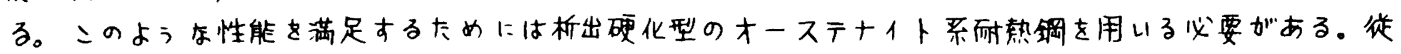
来，航空楆用の耐熱术ルトとしてはA286 合金が用いられているが、洒格が比較的高いため用途に 制限をうける欠点がある。よつて著者うは，含P析出硬化型オーステーイト铜をとりあげ、現在排気八゙ ルブに用いられている $0.3 C-0.3 S_{i}-1 M_{n}-20 C_{r}-11 N_{i}-2 M_{0}-0.2 p-0.005 B^{\Phi}$ 鎆の冷间压造性を主として 改良し、経济的な高温ボルト用铜を网発したので、その材等特性について報告する。

2. 供試材および実姶方法

表 1 供試材標隼化学成分

バルブ用含Pオースデイト铜は $0.3 \% C$ 含 有のためスタッド・ボルト用には使用可能であ るが、六角ボルト用には冷间压造性が不足する

\begin{tabular}{c|c|c|c|c|c|c|c|c}
\hline$C$ & $S_{i}$ & $M_{n}$ & $P$ & $N_{i}$ & $C_{r}$ & $M_{0}$ & $C_{u}$ & $B$ \\
\hline 0.20 & 0.30 & 1.0 & 0.23 & 11.0 & 20.0 & 2.0 & 1.5 & 0.005 \\
\hline
\end{tabular}

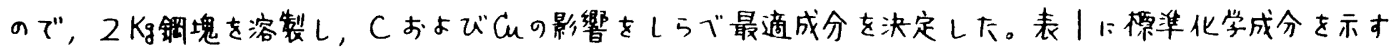
が、供試材は12トンエルー式弧光電気炉で溶製した1000 kg 铜堍を20 mm およで8 mm 中に㞋延

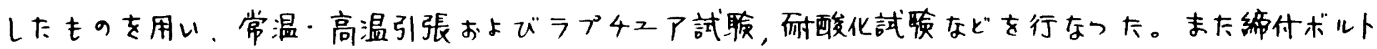

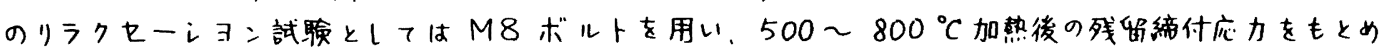
た。

\section{3. 実験结果}

$\mathrm{Cu}$ 添加は $1.5 \%$ で溶体化硬度の低下に有奻で ある。またCを低くすると四、に示すご上く溶体 化硬度を低下するが析出硬化後の硬度も低くなる 表 2 常温楼械的性筫

\begin{tabular}{|c|c|c|c|c|c|}
\hline 熱 処 理 & 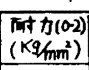 & 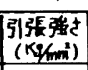 & $\begin{array}{l}\text { 伸 } \\
(\%)\end{array}$ & $\begin{array}{l}\begin{array}{l}\text { 絞 } \\
(\%)\end{array} \\
\end{array}$ & 硬さ \\
\hline $1150^{\circ} \mathrm{C}$ 油冷 & 29 & 67 & 70 & 69 & HRB 84 \\
\hline $1150^{\circ}$ 油冷, $750^{\circ} \times 2 h$ 蛙 & 75 & 107 & 27 & 42 & $\mathrm{HR}_{\mathrm{R}} 33$ \\
\hline
\end{tabular}

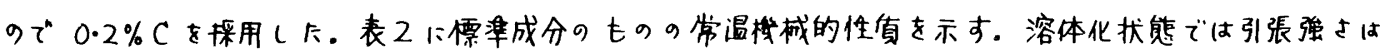

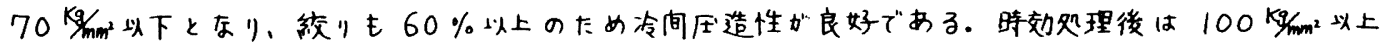
の引張强さを示す。 600,700 および $800^{\circ} \mathrm{C}$ :おる高温引張強さは，それそれ 66, 55 およ

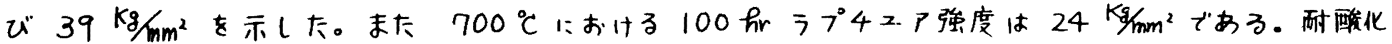

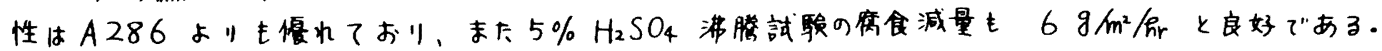

高温术ルトの場合はラプ4ユア強度よ リも庆力喛和がより重要な性值となる。 われわれは简便法としてボルトと同材筫 の台金を缔付け、高温加朝後の残留缔付 力を制定(下。四2が締付ボルトのリラ フセ一レヨン試姶结果で, $500 \sim 800^{\circ} \mathrm{C}$ にそれぞれ3 hr加熱後9残留铲付応力: およばす初期庆力の影皘を示したもので ある。

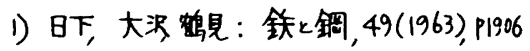

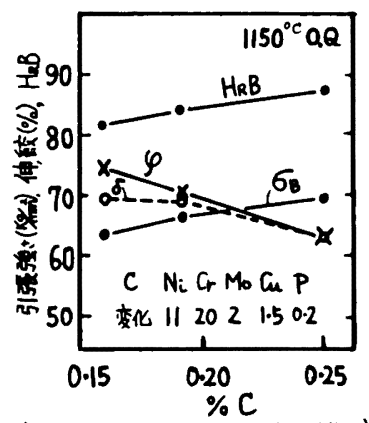

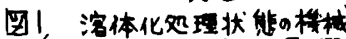

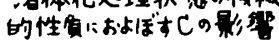

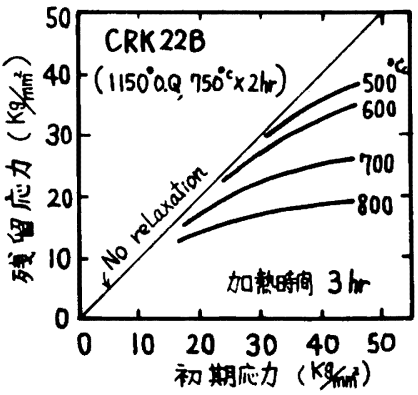

因2 締付ボルトのリラフセーション 


\section{（316）低 S インコロイ800の時効組機と勒变化}

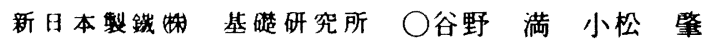

細井桸三

1. まえがき インコロイ800はリフォーマーや高温がス妒の登気発生器等に多用さ㧈ている。著者 ら ${ }^{1)}$ は以前にこの合金の高温長時間時効における脆化举動について報告したが,その後 S量を减少する ことにより脆化特性が大きく变わることを明らかにしたので、時効硬化特性とあわせて報告する。

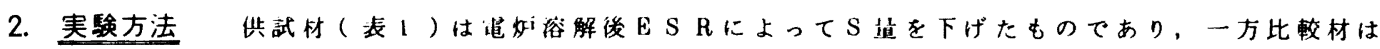

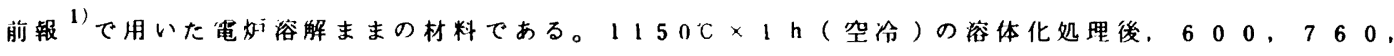

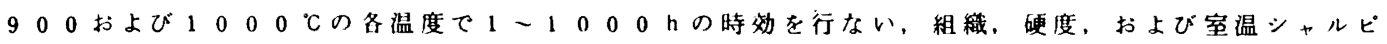

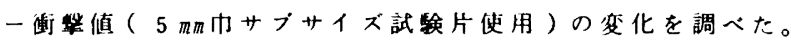

3. 結果と考察为1に示すように供試材は 6000 Cで時矨すると顕著に硬化する。硬化の原因はr 相の全面析出が起るためである。他の温度では年相の析出は起らない。6 $0000^{\circ}$ 時効で相が析出する 点を除くと供試材の洔効組鐵は比較材に類似しているが，供試材においては粒界 $M_{23} \mathrm{C}_{6}$ 粒子のサイス が小く、かつ代連読的である。

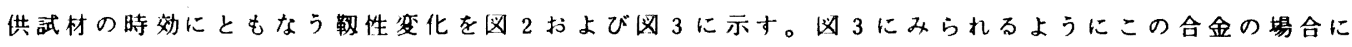
は C 曲線型の脆化特性が傅られる。7 $60{ }^{\circ} \mathrm{C}$ 以上の高温部の脆化は主として炭化物の析出にともなって

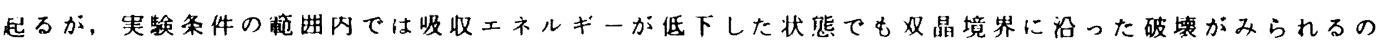

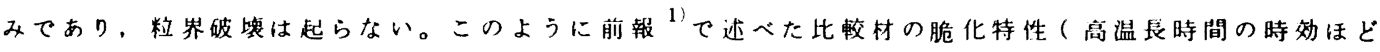

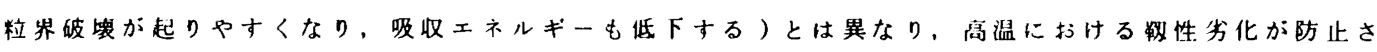

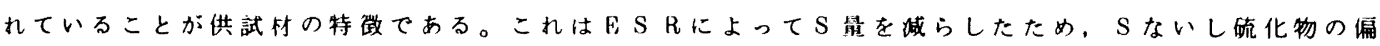
析に起因する粒界脆化因子が軽隇されたこと、ならびに粒兴炭化物の粗大化が㧕制されたことによると 考えられる。一方，低温缡の脆化はで相の形成により粒内が規則化されたためであり，上として粒界お よび双晶境界に沿った破壊が観察される。

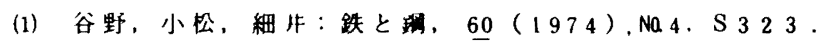

表1供試材抢よび比較材の化学組成(wt.\%)

\begin{tabular}{|c|c|c|c|c|c|c|c|c|c|c|c|c|}
\hline & $\mathrm{C}$ & $\mathrm{Si}$ & $\mathrm{Mn}$ & $\mathrm{Cr}$ & $\mathrm{Ni}$ & $\mathrm{Fe}$ & $\mathrm{Ti}$ & $\mathrm{Al}$ & $\mathrm{P}$ & $\mathrm{S}$ & $\mathrm{O}$ & $\mathrm{N}$ \\
\hline 供試材 & 0.06 & 0.41 & 0.92 & 21.33 & 31.70 & 44.74 & 0.38 & 0.45 & 0.005 & 0.002 & & \\
比较材 & 0.06 & 0.50 & 1.19 & 20.38 & 32.99 & 44.21 & 0.26 & 0.32 & 0.009 & 0.005 & 0.005 & 0.018 \\
\hline
\end{tabular}

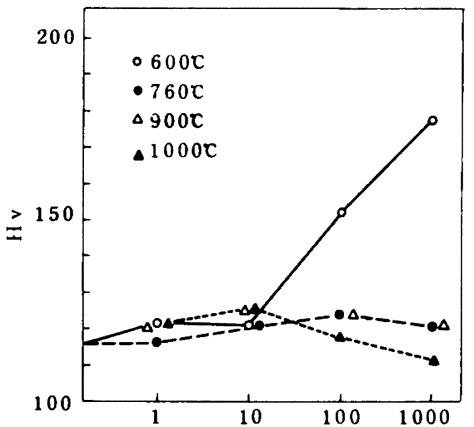

時効時間 $(h)$

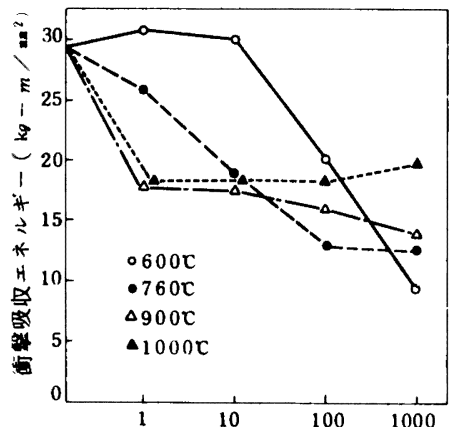

時知時间 (h)

汹2 時奻に上る释性变化

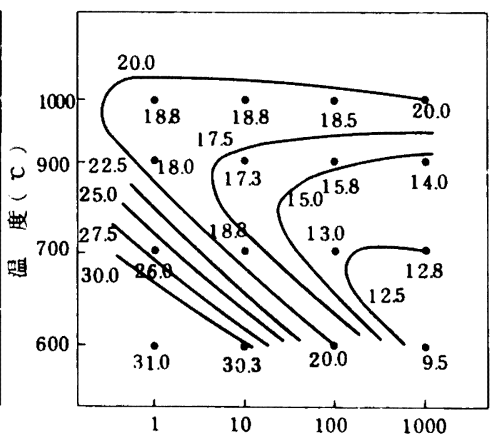

時効時間 (h)

以１時効による硬度变化

因3算街曹值曲绝。

“数字 $\rightarrow$ 街里值〉 